\title{
PENGUATKUASAAN UNDANG-UNDANG DALAM ISU PENJUALAN BARANG TIRUAN: PERBANDINGAN ANTARA MALAYSIA DENGAN UNITED KINGDOM
}

\section{(Enforcement of Law on the Issue of Sale of Counterfeit Goods: A Comparison between Malaysia and United Kingdom)}

Nur Khalidah Dahlan*

nurkhalidahdahlan@ukm.edu.my

Nurdiana Rosmin

nurdianarosmin98@gmail.com

Fakulti Undang-undang, Universiti Kebangsaan Malaysia.

Pengarang koresponden (Corresponding author): *

Rujukan artikel ini (To cite this article): Nur Khalidah Dahlan \& Nurdiana Rosmin. (2022). Penguatkuasaan undang-undang dalam isu penjualan barang tiruan: Perbandingan antara Malaysia denggan United Kingdom. Kanun: Jurnal Undang-undang Malaysia, 34(1), 75-96. http://doi.org. 10.37052/kanun.34(1)no4

\begin{tabular}{|llllll}
\hline $\begin{array}{l}\text { Peroleh: } \\
\text { Received: }\end{array} \quad 23 / 8 / 2021$ & $\begin{array}{l}\text { Semakan: } \\
\text { Revised }\end{array}$ & 30/9/2021 & $\begin{array}{l}\text { Terima: } \\
\text { Accepted: 29/10/2021 }\end{array}$ & $\begin{array}{l}\text { Terbit dalam talian: } \\
\text { Published online }\end{array}$ & $2 / 1 / 2022$ \\
\hline
\end{tabular}

\begin{abstract}
Abstrak
Penjualan barang tiruan merupakan suatu tindakan yang menyalahi undang-undang apabila peniaga meletakkan cap dagangan pengeluar asal pada barangan yang bukan asli. Tindakan ini sering kali dibawa dan dikemukakan di mahkamah mengikut Akta Hak Cipta 1987, Akta Cap Dagangan 1976 dan Akta Perihal Dagangan. Walau bagaimanapun, meskipun terdapat pelbagai penguatkuasaan undangundang untuk memastikan kegiatan ini dapat dihapuskan, masih banyak kes yang melibatkan penjualan barangan tiruan berlaku yang merugikan masyarakat. Melalui kajian ini, kerangka perundangan yang tertentu telah dikenal pasti dapat membendung hal ini daripada berlaku. Perbandingan penguatkuasaan undang-undang antara negara Malaysia dan negara United Kingdom, serta cadangan penambahbaikan juga turut telah dibincangkan dalam artikel ini. Hasil kajian mendapati penguatkuasaan yang sedia ada sudah cukup berkesan. Namun begitu, sekiranya ditambah baik dengan mewujudkan akta yang komprehensif, mencontohi sistem penyelesaian di United Kingdom yang menawarkan
\end{abstract}

(C) Dewan Bahasa dan Pustaka. 2022. This work is licensed under the term of the Creative Commons Attribution (CC BY) (http://creative commons.org/licenses/by/4.0/) 
nasihat dan penyelesaian paling sesuai kepada pengadu secara dalam talian, usaha ini akan dapat mengurangkan bilangan kes penjualan barang tiruan di Malaysia dengan lebih berkesan.

Kata kunci: Penguatkuasaan undang-undang, penjualan barang tiruan, Akta Hak Cipta 1987, Akta Cap Dagangan 1976, Akta Perihal Dagangan, United Kingdom

\begin{abstract}
The sale of counterfeit goods is an illegal act in which dealers place original manufacturer trademarks on non-genuine goods. This offense is often brought to the court under the Copyright Act 1987, the Trade Marks Act 1976, and the Trade Descriptions Act. However, despite having all sorts of enforcement of laws to ensure that this offense is eradicated, there are still countless cases of sales of counterfeit goods that are detrimental to society. This study was conducted to examine the effectiveness of the existing legal frameworks and the standard operating procedure in Malaysia that governs this issue. Through this study, specific legal frameworks were identified to prevent the reoccurrence of this offense. The differences in the enforcement of law between Malaysia and the United Kingdom as well as suggestions for improvement were also discussed in this article. The result found that existing legal enforcement is effective enough. However, if the enforcement were to be further improved, such as by creating a comprehensive act and emulating a settlement system in the United Kingdom that offers the most appropriate advice and solution to complainants online, this effort can certainly reduce the number of cases of counterfeit goods sold in Malaysia more effectively.
\end{abstract}

Keywords: Law enforcement, sale of counterfeit goods, Copyright Act 1987, Trade Marks Act 1976, Trade Descriptions Act, United Kingdom

\title{
PENDAHULUAN
}

Penjualan barang tiruan ialah tindakan yang menyalahi undang-undang apabila peniaga meletakkan cap dagangan pengeluar asal pada barang yang bukan asli dan tanpa izin pemilik cap dagangan tersebut (Sonmez et al., 2013). Barang tiruan merupakan penghasilan produk yang salah di sisi undang-undang apabila produk tersebut mempunyai ciri-ciri yang sama dengan produk asli tetapi kebiasaannya kualitinya akan lebih rendah dalam aspek prestasi dan kebolehpercayaan (Mackey \& Liang, 2011). 
Turut diterangkan oleh Clunas (1991), bahawa penjualan barang tiruan ini merupakan satu fenomena yang telah lama wujud. Namun begitu, hal ini hanya mula menimbulkan isu perundangan kepada syarikat perniagaan bermula pada tahun 1970 sehinggalah kini.

Memang tidak dapat dinafikan kegiatan penjualan barang tiruan semakin berleluasa meskipun terdapat pelbagai peruntukan perundangan dalam pelbagai sudut untuk mengawal selia isu ini. Hal ini demikian disebabkan pemikiran masyarakat yang menganggap pemilikan barangan berjenama sebagai lambang prestij seseorang (George W. Abott, Lee S Sporn, 1999). Namun begitu tidak semua orang berkemampuan memiliki barangan berjenama kerana harganya yang mahal. Oleh sebab kehendak pengguna dan keinginan peniaga untuk mengaut keuntungan, berlakulah kegiatan perdagangan barang tiruan dengan pengeluaran barangan tiruan yang hampir sama dengan barangan asli dengan harga yang lebih rendah.

Kesukaran untuk membezakan antara produk asli dan produk tiruan juga merupakan suatu cabaran untuk membanteras kegiatan penjualan barang tiruan ini. Perkembangan kemajuan teknologi yang semakin canggih pada zaman kini dalam pembuatan produk tiruan menyukarkan pengguna untuk membezakan produk asli dan produk tiruan (Gentry et al., 2006). Ciri-ciri perbezaan kadang kala sukar dilihat dengan mata kasar dan perlu menggunakan peralatan tertentu untuk melihat ciri-ciri khas yang dihasilkan oleh empunya cap dagang. Antara jenis-jenis barang tiruan yang banyak terdapat di pasaran termasuklah pakaian, makanan, ubat-ubatan, alat ganti kereta, jam tangan, alat tulis, bahan petroleum, barangan kulit, rokok, arak, kasut, cermin mata, barangan elektrik, alat komunikasi, perkakasan komputer, cakera optik dan pita video.

Kerajaan Malaysia juga telah mengambil pelbagai langkah untuk menyedarkan penjual dan pengguna bahawa kemunculan produk tiruan memberikan kesan negatif kepada ekonomi dunia. Menurut Agarwal (2016), aktiviti peniruan produk telah memberikan impak yang besar kepada ekonomi dan menjejaskan kutipan cukai sesebuah negara. Walau bagaimanapun, tidak diketahui sejauh mana lapisan masyarakat melihat isu tersebut.

Hasil barangan yang terhasil daripada inovasi dan kreativiti pengasas tersendiri merupakan tujuan utama seseorang memulakan perniagaan. Secara tidak langsung perniagaan ini dapat meningkatkan pembangunan ekonomi negara. Oleh yang demikian, pengasas perniagaan atau ahli perniagaan memerlukan peruntukan perundangan yang lebih utuh untuk 
melindungi hak dan kepentingan mereka. Undang-undang harta intelek telah diperuntukkan untuk melindungi hak cipta. Namun begitu, ketika peniaga lain menjual barang tiruan secara haram, kerangka perundangan yang mana satukah yang memainkan peranan yang penting untuk mengawal selia tindakan tersebut? Sewajarnyalah perlindungan terhadap pengasas, peniaga dan pengguna amatlah penting untuk dilindungi haknya oleh pihak-pihak yang terlibat dalam isu ini.

Kebiasaannya, barang tiruan ini dibawa masuk melalui pintu sempadan dan pelabuhan sama ada secara sah ataupun haram. Modus operandi kegiatan pengedaran dan penjualan barang tiruan ini biasanya dengan tidak menggunakan sebarang resit penjualan. Pembayaran dibuat secara tunai (Chaudhry, 2017).

Akta Hak Cipta 1987 menumpukan pada pelanggaran hak cipta apabila seseorang menghasilkan karya asli seseorang sama ada dalam bentuk buku, lagu, lukisan, filem, atau rakaman tanpa izin pemilik hak cipta tersebut. Akta ini tertumpu pada hukuman atas kesalahan penghasilan barang tiruan berbentuk karya.

Akta Perihal Dagangan 2011 seksyen 8(2), pula menerangkan bahawa ianya merupakan suatu kesalahan apabila mana-mana orang menggunakan suatu perihal dagangan palsu bagi apa-apa barang-barang seolah-olah barang-barang itu tertakluk pada apa-apa hak yang berhubung dengan cap dagangan berdaftar. Skop barang tiruan menurut Akta Perihal Dagangan 2011 ini tidak tertumpu kepada jenis-jenis barang sahaja seperti yang dinyatakan dalam Akta Hak Cipta 1987.

Akta Jualan Barangan 1957 pula merupakan suatu akta yang digubal khusus untuk mengawal selia kontrak jualan barang-barangan. Seksyen 16(1)(b) menyatakan sesuatu barangan hendaklah mempunyai kualiti boleh dagang, syarat-syarat yang mesti dipatuhi adalah;

1. Pembeli membeli barangan itu secara deskripsi; dan

2. Barangan itu dibeli daripada penjual yang biasa menjual barangan itu.

\section{PENGUATKUASAAN UNDANG-UNDANG DI MALAYSIA}

Pihak berkuasa utama yang mempunyai tanggungjawab untuk mengawal selia isu penjualan barang tiruan ialah Kementerian Perdagangan Dalam Negeri dan Hal Ehwal Pengguna (KPDNHEP). KPDNHEP ditubuhkan pada 27 Oktober 1990 dan matlamat penubuhannya adalah untuk 
menggalakkan pembangunan perdagangan dalam negeri yang berdaya maju, berdaya saing, dan berdaya mampan, khususnya dalam sektor perdagangan pengedaran. Pada masa yang sama, mereka juga melindungi kepentingan dan hak-hak pengguna.

Dari segi perundangan pula, setakat ini Malaysia mempunyai beberapa akta perundangan yang mengawal selia hal berkaitan penjualan barang tiruan. Antaranya termasuklah, Akta Hak Cipta 1987, Akta Perihal Dagangan 2011, Akta Jualan Barangan 1957, Akta Perlindungan Pengguna 1999, dan pertubuhan Tribunal Tuntutan Pengguna (TTP).

Akta Hak Cipta 1987 adalah untuk melindungi hak cap dagangan empunya mengenai terhadap sesuatu barang. Denda tidak kurang daripada RM4000 dan tidak melebihi RM40000 akan dikenakan jika terdapat pelanggaran hak cipta.

Akta Perihal Dagangan 2011 diperkenalkan bertujuan untuk menggalakkan amalan perdagangan yang baik. Akta ini melarang hal yang berkaitan dengan dagangan dan penyataan, pengendalian dan amalan yang palsu, atau mengelirukan berhubung dengan pembekalan barang-barang dan perkhidmatan. Akta ini mewujudkan peruntukan bagi perkara yang berkaitan atau bersampingan dengannya. Berdasarkan seksyen 8(2), sekiranya seseorang disabit bersalah atas kesalahan mengguna perihal dagangan palsu bagi apa-apa barang seolah-oleh barangan tersebut tertakluk pada apa-apa hak yang berhubungan dengan cap dagangan yang berdaftar, membekalkan, menawarkan, mempunyai milikan, jagaan atau kawalan, mereka akan dikenakan denda tidak lebih RM30000 atau dipenjara tidak lebih dari 5 tahun atau kedua-duanya sekali.

Akta Jualan Barangan 1957 memperuntukkan beberapa terma tersirat untuk mengimbangi kuasa penjual dengan pembeli. Tanggungan yang dikenakan kepada penjual dalam terma tersirat ini melindungi pembeli dalam suatu transaksi atau jual beli. Antara terma yang diperuntukkan dalam akta ini termasuklah:

1. Barang yang dijual mestilah sama dengan perihal yang dinyatakan,

2. Barangan mempunyai kualiti boleh dagang,

3. Barang yang dibeli boleh digunakan bersesuaian dengan tujuannya dibuat serta pembeli boleh memiliki barang dengan aman.

Akta Perlindungan Pengguna 1999 pula telah mewujudkan suatu badan bebas Tribunal Tuntutan Pengguna (TTP). TTP seperti "mahkamah 
peribadi" atau alternatif kepada mahkamah sivil. Tuntutan yang dibuat melalui TTP adalah lebih berpatutan dan prosesnya lebih cepat bagi nilai tuntutan kurang daripada RM25000. Proses tuntutan ini tidak melibatkan peguam daripada kedua-dua pihak. Sebaliknya, penuntut sendiri yang akan membicarakan kesnya di mahkamah dengan bantuan ahli Tribunal. Bagi tuntutan yang melebihi RM30000 pula, tuntutan tersebut akan disiasat di bawah Akta Pengubahan Wang Haram 2001.

Namun begitu, akta-akta yang sedia ini tidak mampu untuk mengawal kegiatan ini secara keseluruhannya. Hal ini merupakan suatu cabaran yang besar kerana tiada keseragaman dalam akta perundangan untuk melindungi pihak penjual serta pihak pengguna dalam situasi penjualan barang tiruan.

Penguatkuasaan pihak berkuasa berkenaan isu penjualan barang tiruan ini boleh dikatakan agak lemah. Menteri Perdagangan Dalam Negeri dan Hal Ehwal Pengguna menyatakan antara masalah utama yang dihadapi oleh KPDNHEP dalam artikel 'KPDNHEP tak cukup penguat kuasa'. Beliau menyatakan kekurangan pegawai menyebabkan KPDNHEP tidak berupaya untuk memantau aktiviti peniaga warganegara sepanjang masa. Ekoran itu, mereka berdepan kesukaran untuk menempatkan penguat kuasa sepanjang masa bagi memantau pasar borong dan pasar harian berkenaan. Buat masa ini, pendekatan penguatkuasaan berjadual dilaksanakan untuk mengekang masalah ini. Hal ini berlaku kerana pihak berkuasa tidak mampu untuk memantau kegiatan penjualan barang tiruan pada setiap masa (Nurazreen, 2011).

\section{Kes-kes Berkaitan dengan Isu Penjualan Barang Tiruan yang Berlaku di Malaysia}

Kes-kes utama berkaitan dengan isu penjualan barang tiruan yang berlaku di Malaysia adalah seperti yang berikut:

- Jasmine Food Corporation Sdn Bhd v Leong Wai Choon \& Anor (2016)

- H \& R Johnson Tiles Ltd \& Anor V H \& R Johnson (M) Bhd [1998] 4 MLJ 13

- Hew Chai Seng (t/a Pertiland Trading Co) v Metronic Integrated System Sdn Bhd \& Anor (2017)

- Tan Kim Hock Product Centre Sdn Bhd \& Anor V Tan Kim Hock Tong Seng Food Industry Sdn Bhd (2018). 
Kes Jasmine Food Corporation telah memakai peruntukan dalam Akta Hak Cipta 1987, Akta Cap Dagangan 2019 serta prinsip undangundang tort kelirupaan. Kelirupaan merupakan perlindungan kepada pihak teraniaya sekiranya beliau telah terpedaya dengan tipu helah seseorang sama ada melalui perkataan atau perbuatan. Dalam kes ini, plaintif merupakan sebuah syarikat pengedaran beras yang terkemuka yang didaftarkan di Malaysia dan merupakan sebuah anak syarikat di bawah Padiberas Nasional BHD ('BERNAS'). Plaintif terlibat dalam perniagaan penghasilan serta pengedaran pelbagai jenis jenama beras. Defendan merupakan seorang pemilik dengan kedai runcit yang menjual beras. Plaintif serta pegawai dari Kawal Selia Padi \& Beras, Kementerian Pertanian dan Industri Asas Tani telah mengadakan pemeriksaan di kedai defendan dan mendapati defendan menjual beras jenama tiruan. Plaintif memfailkan aduan di mahkamah, dan mahkamah membenarkan tuntutan plaintif berdasarkan beberapa hujahan; iaitu terdapatnya pelanggaran hak cipta, pelanggaran cap dagangan, gangguan perdagangan yang menyalahi undang-undang serta pelanggaran undang-undang tort kelirupaan yang boleh mengelirukan pengguna.

Kes Johnson v Johnson, Re pula mengaplikasikan peruntukan di bawah Akta Perihal Dagangan 2011. Dalam kes ini, plaintif, Johnson \& Johnson ialah pemilik berdaftar cap dagangan 'Johnson's'. Plaintif mendapati bahawa lampin bayi yang dihasilkan oleh defendan bukan produk pemohon yang dilabelkan dengan cap dagangan 'Johnson's' dalam grafik yang serupa dengan grafik label produk pemohon telah didapati dijual secara terbuka di pasaran. Defendan menghujahkan bahawa melalui label bungkusannya, pembeli tidak akan menyangka bahawa lampin bayi itu bukan produk plaintif. Plaintif memohon "perintah perihal dagangan" di bawah seksyen 16(1) Akta Perihal Dagangan 2011 supaya lampin tersebut tidak dikilangkan, diedar, dijual, dan ditawarkan untuk penjualan oleh plaintif atau wakil-wakil mereka, yang berlabelkan cap dagangan yang serupa dengan cap dagangan plaintif. Persoalan yang timbul adalah sama ada perintah perihal dagangan di bawah seksyen 16 diperlukan bagi kes barang tiruan seperti ini. Mahkamah memutuskan cap dagangan yang digunakan oleh defendan, walaupun cap dagangannya kelihatan seperti sama, namun disebabkan hal ini tidak menimbulkan sebarang kekeliruan, maka dengan itu, cap dagangan yang digunakan oleh pihak defendan tidaklah jatuh di bawah definisi perihal dagangan palsu berdasarkan seksyen 7 Akta Perihal Dagangan 2011. 
Dalam kes Hew Chai Seng v Metronic Integrated System Sdn Bhd \& Anor pula, Akta Cap Dagangan 1976 telah digunakan. Mahkamah dalam kes ini juga merujuk keputusan kes Johnson $\mathrm{v}$ Johnson, Re yang telah diputuskan. Plaintif ialah pemilik tanda niaga bernama "FERTI" telah berdaftar dalam Kelas 1 untuk baja pada 19 Mac 1983 dan Kelas 16 untuk bahan-bahan yang berkaitan dengan tujuan pengiklanan dan promosi pada 6 Mac 1993. Pertikaian timbul apabila plaintif mendapati bahawa defendan telah menggunakan tanda niaga "FERTI" dalam iklan defendan, dalam akhbar tempatan dan laman web mereka. Defendan menyatakan penggunaan tanda niaga "FERTI" merupakan penggunaan yang dipakai oleh orang ramai, namun defendan gagal untuk membuktikan hujahannya itu, dan defendan disabitkan dengan kesalahan melanggar hak cap dagangan plaintif.

Dalam Tan Kim Hock Product Centre Sdn Bhd \& Anor v Tan Kim Hock Tong Seng Food Industry Sdn Bhd pula, responden ('TKTS Food Industry') telah berjaya memperoleh perintah ex parte daripada Mahkamah Tinggi di bawah seksyen 9 Akta Perihal Dagangan 2011 terhadap perayu. Perintah perihal dagangan ini diberikan oleh mahkamah kerana jika tidak berbuat demikian hal ini mungkin akan mengelirukan pengguna terhadap produk di pasaran oleh seseorang atau mana-mana firma yang tidak diberi kuasa oleh TKTS Food Industry pada masa hadapan. Cap dagangan perayu menggunakan huruf " $T$ " bersama-sama dengan pokok kelapa manakala di tengah pokok kelapa terdapat huruf "S" (cap dagangan) dan mempunyai pembungkusan yang mengelirukan kerana hampir serupa dengan pembungkusan TKTS Food Industry dari segi warna, bentuk dan butiran pada bungkusan bukan produk TKTS Food Industry. Maka dengan itu, produk perayu diisytiharkan sebagai produk tiruan yang mempunyai cap dagangan palsu.

Secara ringkasnya, kes Jasmine Food Corporation Sdn Bhd mengunakan peruntukan Akta Hak Cipta 1987 dan Akta Cap Dagangan 1976. Kes ini adalah berkenaan dengan pelanggaran hak cipta dan cap dagangan beras yang diniagakan oleh plaintif. Kemudian kes Johnson v Johnson pula, isu yang ditumpukan adalah tentang cap dagangan barangan, maka di sini Akta Perihal Dagangan 2011 digunakan kerana plaintif ingin membuat tuntutan perintah perihal dagangan untuk menyekat defendan daripada menggunakan cap dagangan "Johnson" yang serupa seperti kepunyaan plaintif. Kes Hew Chai Seng turut mempunyai isu mengenai hak cap dagangan seperti kes Johnson v Johnson. Kes Tan Kim Hock 
Product Centre Sdn Bhd \& Anor V Tan Kim Hock Tong Seng Food Industry Sdn Bhd pula adalah tentang responden berjaya memperoleh perintah ex parte daripada Mahkamah Tinggi di bawah Akta Perihal Dagangan 2011 terhadap perayu untuk melarang perayu menggunakan cap dagangan yang sama kerana hal ini boleh mengelirukan pengguna.

Berdasarkan empat kes utama tersebut, dapat dilihat bahawa kes berkenaan barang tiruan yang sering kali dibawa kepada peringkat mahkamah tinggi ialah kes berkenaan hak cap dagangan dan hak cipta. Akta yang digunakan tertumpu pada tiga akta utama, iaitu, Akta Hak Cipta 1987, Akta Cap Dagangan 1976 (kini adalah Akta Cap Dagangan 2019), dan Akta Perihal Dagangan 2011.

Oleh itu, tidak dapat dinafikan bahawa penguatkuasaan undangundang adalah amatlah penting untuk membanteras kegiatan penjualan barang tiruan. Bab seterusnya akan menerangkan perundangan dan piawaian prosedur operasi (standard operating procedure) yang wujud dalam isu pengawalan kegiatan penjualan barang tiruan di Malaysia.

\section{Contoh Kes Luar Negara}

Merujuk laporan Organisation for Economic Co-operation Development (OECD), sebanyak 67\% barangan yang dijual di laman web atas talian seperti e-Bay, Alibaba, Taobao, Amazon, Lazada ialah barangan palsu. Maka tidak dinafikan lagi bahawa kebanyakan kes penjualan barang tiruan ialah barangan yang dijual secara dalam talian. Namun begitu terdapat juga kes-kes barang tiruan yang melibatkan pembelian di kedai-kedai. Subtopik ini membincangkan beberapa kes yang melibatkan kes penjualan barang tiruan di negara-negara luar.

Kes Montres Rolex S.A.v Ricardo de AG(2005) 37 IIC 573. Dalam kes ini, jam berjenama Rolex tiruan dijadikan barang lelongan di suatu laman web lelong bernama Ricardo. Kenyataan bahawa jam tersebut merupakan jam palsu telah dinyatakan di laman web tersebut. Ekoran subjek lelongan itu melibatkan barangan jenama tiruan, syarikat pengusaha jam Rolex iaitu Montres Rolex S.A mengambil tindakan terhadap laman web lelongan tersebut atas kesalahan melanggar undang-undang hak intelek serta kesalahan penjualan barang tiruan. Mahkamah Supreme Jerman memutuskan bahawa kenyataan jelas bahawa jam tersebut adalah palsu tidak menafikan tanggungjawab laman web tersebut sebagai platform perniagaan untuk mengelakkan perniagaan barang tiruan, atau frod. 
Responden turut mempunyai tanggungjawab untuk tidak menggunakan cap dagangan pihak perayu untuk menjual barangan berjenama tersebut. Maka dengan itu, responden didapati bersalah dalam kes ini.

Kes penyitaan Monosodium Glutamate di Laos, 2014. Suatu kilang pertanian telah mendaftarkan hak cap dagangannya di Laos. Kemudian, mereka sedar bahawa terdapat barangan palsu jenama mereka dipasarkan di pasar tempatan. Kegiatan penjualan barang palsu itu telah menjejaskan imej syarikat dan jenama mereka. Penyitaan barangan telah dilakukan terhadap peniaga yang menjual barang tiruan, namun sebarang denda tidak dikenakan terhadap mereka oleh pihak berkuasa kerana pesalah merupakan pesalah kali pertama. Undang-undang di Laos menyatakan bahawa bagi pesalah kali pertama, mereka tidak dikenakan tindakan undang-undang untuk dipenjarakan atau didenda. Masyarakat awam telah mengkritik tindakan pihak berkuasa. Merujuk kes ini, boleh dilihat betapa pentingnya wujudnya penguatkuasaan undang-undang yang jelas untuk mengawal selia kegiatan penjualan barang tiruan. Ketiadaan peruntukan undang-undang yang jelas di negara tersebut telah mengakibatkan peniaga mengalami kerugian yang besar, mereka juga tidak berupaya untuk menuntut kerugian yang dialaminya.

\section{KAWALAN PERUNDANGAN BAGI KEGIATAN PENJUALAN BARANG TIRUAN}

Kegiatan penjualan barang tiruan ini haruslah dibanteras secara habishabisan kerana isu ini bukan sahaja melibatkan pemain pasaran, malahan pengguna, serta ekonomi negara juga akan terjejas jika aktiviti ini semakin menular. Kegiatan penjualan barang tiruan ini turut dapat menjejaskan kesihatan atau nyawa seseorang jikalau barang tiruan tersebut melibatkan barangan seperti makanan, ubat-ubatan, bahagian komponen kereta dan sebagainya. Oleh itu, untuk mengelakkan keadaan yang tidak diingini berlaku, perlindungan hak dan penguatkuasaan undang-undang haruslah dilaksanakan untuk membendung masalah ini. Penguatkuasaan yang efektif dan kondusif dapat memastikan perniagaan yang dilaksanakan adalah sihat, serta memastikan perkembangan ekonomi negara tidak tergugat. Penguatkuasaan juga dapat memberikan pilihan yang lebih banyak kepada pengguna untuk membeli barangan kerana mereka tidak perlu risau tentang barangan yang mereka beli itu barangan tiruan atau tidak. Selain itu juga, pelaksanaannya dapat memastikan keselamatan 
pengguna serta secara tidak langsung mengelakkan sebarang perkara yang tidak diingini berlaku.

Oleh itu, pihak berkuasa haruslah memainkan peranan masing-masing untuk memastikan peruntukan undang-undang dapat dikuatkuasakan dengan efektif supaya kegiatan penjualan barang tiruan ini dapat dibanteras. Subtopik sebelumnya telah diterangkan tentang kawalan perundangan barang tiruan di Malaysia. Untuk subtopik ini pula akan membincangkan jenis penguatkuasaan undang-undang antarabangsa, amalan undangundang yang diamalkan di United Kingdom serta sama ada mekanisme undang-undang yang sedia ini mencukupi dan efektif untuk membendung kegiatan penjualan barang tiruan ini.

\section{Penguatkuasaan Undang-undang Antarabangsa}

Penguatkuasaan undang-undang antarabangsa adalah penting, kerana melalui triti dan perjanjian undang-undang antarabangsa, kegiatan penjualan barang tiruan ini dapat ditangani secara menyeluruh dan membolehkan pihak-pihak yang terkesan mengambil tindakan dari satu negara ke satu negara yang lain.

Kemasukan barangan tiruan di pasaran antarabangsa merupakan fenomena biasa yang sering kali berlaku. Walaupun produk dan barangan tulen masih lagi mendominasi pasaran, namun barangan palsu juga telah secara tidak langsung berjaya menembusi kebanyakan sekatan undangundang di sempadan antarabangsa. Kejayaan produk tiruan merentasi sempadan itu menyebabkan masyarakat secara tidak langsung dan tanpa disedari membeli barang tiruan yang terdapat di pasaran luar. Oleh itu, adalah penting untuk mengkaji masalah yang timbul dan sekatan undangundang yang dilaksanakan pada taraf antarabangsa ini.

Selain itu, undang-undang antarabangsa ini juga penting kerana dapat memberikan hak dan kepentingan umum untuk melindungi pemain pasaran asing yang mempunyai sistem undang-undang yang berbeza bergantung pada negara masing-masing.

Secara asasnya, kawalan perundangan undang-undang bagi hak harta intelek bersifat wilayah (territorial), oleh itu, undang-undang yang memberikan perlindungan dan penguatkuasaan adalah berbeza-beza antara negara-negara yang terlibat. Undang-undang bersifat wilayah, tetapi perniagaan yang dilaksanakan oleh peniaga pula tidak mempunyai batasan. Apabila sesuatu perniagaan boleh mencecah taraf antarabangsa 
maka keadaan tersebut adalah lebih baik bagi mereka. Seterusnya, hal ini mewujudkan kelompongan dalam bentuk perlindungan yang diberikan kepada perniagaan yang dijalankan oleh ahli peniaga dari negara lain. Oleh itu, untuk memastikan perkembangan ekonomi yang dapat memanfaatkan semua pihak, suatu bentuk perlindungan antarabangsa yang lebih utuh haruslah dilaksanakan supaya yang wujud dapat dikurangkan ekoran kelompongan tersebut.

Pelbagai usaha telah dilaksanakan pihak-pihak di seluruh dunia, dan ekoran daripada usaha tersebut, beberapa triti dan perjanjian antarabangsa telah diwujudkan sejak abad ke-19 lagi untuk memberikan perlindungan taraf antarabangsa terhadap hak harta intelek ini. Kebanyakan triti dan perjanjian antarabangsa ini ditadbir oleh World Intellectual Property Organization (WIPO). Perjanjian TRIPS pula ditadbir oleh World Trade Organization (WTO). WIPO merupakan badan yang diwujudkan oleh United Nations pada tahun 1974, manakala WTO pula ialah badan yang diwujudkan daripada perjanjian Marrakesh pada tahun 1994.

\section{Triti dan Perjanjian Antarabangsa yang Melindungi Hak Harta Intelek}

(1) Konvensyen Paris dan Perlindungan Hak Perindustrian 1883

Konvensyen Paris ini merupakan triti berkenaan hak harta intelek terawal yang diwujudkan untuk memberikan perlindungan antarabangsa bagi industri yang berkaitan di luar sana. Perjanjian ini juga merupakan perjanjian pertama yang menyentuh aspek undang-undang berkenaan hak cipta dan cap dagangan. Konvensyen ini pada awalnya ditandatangani oleh 11 negara sahaja pada tahun 1883, kemudian bilangan negara yang menyertai konvensyen ini meningkat kepada 14 pada 7 Julai 1884 ekoran penyertaan United Kingdom, Tunisia dan Ecuador. Sehingga tahun 2020 ini, sebanyak 177 negara menyertainya. Negara Malaysia menyertai konvensyen ini pada 1 Januari 1989. Konvensyen ini tidak membentuk undang-undang yang seragam dan komprehensif untuk dipraktikkan oleh semua negara ahli, sebaliknya memperuntukkan satu kerangka perundangan yang fleksibel untuk perlindungan hak perindustrian. Secara umumnya peruntukan perlindungan bagi hak harta intelek dalam konvensyen ini terdiri daripada tiga kategori: layanan kebangsaan, hak keutamaan dan prinsip common rules. 
(i) Layanan kebangsaan

Layanan kebangsaan bermaksud setiap negara yang menyertai konvensyen ini perlu mematuhi Perkara 2(1) Konvensyen Paris yang telah memperuntukkan bahawa setiap negara haruslah memberikan kepentingan yang sama terhadap negara ahli berkenaan perlindungan hak perindustrian seperti kepentingan itu akan dilaksanakan di dalam negara sendiri. Sebagai contoh, jika pihak Malaysia ingin memohon hak cap dagangan di United Kingdom, dan kedua-dua negara ini merupakan negara yang telah meratifikasi konvensyen ini, pihak Malaysia haruslah diberikan hak yang sama oleh pihak United Kingdom seperti negara tersebut memberikan hak kepada ahli warganegaranya. Perkara 3 juga telah memperuntukkan bahawa negara yang bukan ahli juga layak mendapat layanan kebangsaan ini sekiranya pihak daripada negara bukan ahli tersebut bermastautin di negara lain.

(ii) Hak keutamaan

Seterusnya, konvensyen ini adalah penting kerana konvensyen ini memperkenalkan prinsip hak keutamaan. Hak keutamaan bermaksud mana-mana pihak yang membuat permohonan terlebih dahulu, iaitu enam bulan sebelum permohonan cap dagangan akan diberikan keutamaan untuk mendaftarkan cap dagangan itu secara sah. Contohnya, Pihak A mendaftar cap dagangannya pada Januari 2020 di Malaysia, manakala pihak B pula mendaftar cap dagangannya pada Februari 2020 di United Kingdom, keutamaan akan diberikan kepada pihak A. Prinsip ini dapat mengelakkan berlakunya pertindihan pendaftaran cap dagangan serta dapat mengelakkan masalah peniruan cap dagangan berlaku. Prinsip hak keutamaan ini wujud di kedua-dua negara, Malaysia dan United Kingdom seperti yang diperuntukkan dalam seksyen 70 Akta Cap Dagangan 2019 - Malaysia, dan seksyen 35 Akta Cap Dagangan 1994 - United Kingdom.

\section{(iii) Common rules}

Prinsip common rules pula ialah prinsip standard minimum berkaitan dengan perlindungan harta intelek yang perlu dipatuhi negara ahli. Negara ahli tersebut haruslah menerapkan peruntukan tersebut dalam perundangan tempatan masing-masing. 


\section{(2) Konvensyen Berne 1886}

Konvensyen Berne memperuntukkan standard perlindungan bagi hak cipta yang merangkumi karya seni seperti novel, cerpen, puisi, persembahan, nyanyian, opera, lukisan, ukiran dan karya seni bina. Konvensyen ini telah dimeterai pada 9 September 1886 oleh negara Belgium, France, Germany, Haiti, Italy, Liberia, Spain, Switzerland, Tunisia dan United Kingdom. Malaysia menyertai konvensyen ini pada 1 Oktober 1990. Prinsip asas yang wujud dalam Konvensyen Berne ialah: layanan kebangsaan, pengecualian formaliti, tempoh perlindungan minimum dan hak eksklusif minimum.

\section{(3) Perjanjian Vienna 1973 (Vienna Agreement Establishing an} International Classification of the Figurative Elements of Marks 1973)

Perjanjian Vienna ialah perjanjian berkaitan dengan Klasifikasi Antarabangsa bagi elemen bergambar sesuatu cap dagangan. Hanya terdapat 29 negara sahaja yang menyertai perjanjian ini setakat 2020. Malaysia telah menyertai Perjanjian ini pada 28 Jun 2007 yang berkuat kuasa 28 September 2007, manakala United Kingdom belum lagi menyertai perjanjian ini.

(4) TRIPS 1994 (Agreement on Trade-Related Aspects of Intellectual Property Rights 1994)

Perjanjian TRIPS ini termeterai daripada perjanjian Marrakesh yang menubuhkan WTO, yang ditandatangani di Marrakesh, Morocco pada 15 April 1994 dan berkuat kuasa pada 1 Januari 1995. Perjanjian ini mengawal selia pelbagai aspek berkenaan dengan harta intelek termasuklah hak cap dagangan dan kegiatan pemalsuan produk. Perjanjian ini ditadbir oleh WTO, iaitu satu-satunya organisasi antarabangsa yang mengawal selia peraturan perdagangan negara-negara di dunia. Malaysia dan United Kingdom menyertai perjanjian ini pada 1 Januari 1995.

Tujuan Perjanjian TRIPS adalah untuk memastikan standard perlindungan yang memadai wujud di semuanegara yang menganggotainya. Perjanjian TRIPS meluaskan skop perlindungan konvensyen antarabangsa yang terdahulu dengan meletakkan standard minimum perlindungan hak harta intelek dalam semua bidang harta intelek yang perlu dipatuhi oleh semua negara anggota WTO. 
Jadual 1 Triti, Persatuan dan perjanjian antarabangsa yang melindungi hak intelek.

\begin{tabular}{|l|l|}
\hline Tahun & $\begin{array}{l}\text { Triti, persatuan dan perjanjian antarabangsa yang melindungi } \\
\text { hak intelek }\end{array}$ \\
\hline 1883 & Konvensyen Paris dan Perlindungan Hak Perindustrian \\
\hline 1886 & Konvensyen Berne \\
\hline 1892 & Protokol Madrid \\
\hline 1973 & $\begin{array}{l}\text { Perjanjian Vienna (Vienna Agreement Establishing an International } \\
\text { Classification of the Figurative Elements of Marks) }\end{array}$ \\
\hline 1974 & World Intellectual Property Organization (WIPO) \\
\hline 1994 & World Trade Organization (WTO) \\
\hline 1994 & $\begin{array}{l}\text { TRIPS (Agreement on Trade-Related Aspects of Intellectual } \\
\text { Property Rights) }\end{array}$ \\
\hline
\end{tabular}

Perjanjian ini merangkumi lima isu utama:

(i) Pemakaian prinsip asas GATT (The General Tariffs and Trade) dan juga perjanjian harta intelek antarabangsa yang relevan.

(ii) Peruntukan hak-hak harta intelek yang mencukupi.

(iii) Peruntukan langkah-langkah penguatkuasaan yang berkesan di sesebuah Negara.

(iv) Penyelesaian pertikaian multilateral dalam kalangan negara anggota WTO.

(v) Perjanjian khusus tentang peraturan-peraturan peralihan bagi memastikan penyertaan dalam sistem baharu.

Peruntukan utama Perjanjian TRIPS ialah prosedur dan remedi di bawah perundangan domestik bagi memastikan keberkesanan penguatkuasaan harta intelek. Peruntukan-peruntukan ini menyediakan prosedur tindakan sivil dan pentadbiran serta remedi. Prosedur berkenaan jenayah dan penalti hendaklah diwujudkan dalam perundangan atau institusi pentadbiran domestik selaras dengan prinsip am yang tertentu. Kewajipan untuk memastikan pelaksanaan Perjanjian TRIPS dalam sesuatu tempoh yang tertentu adalah terpakai kepada semua negara ahli. 
Malaysia telah diberikan tempoh 5 tahun untuk menepati peruntukan Perjanjian TRIPS, iaitu sehingga 1 Januari 2000. Malaysia telah mewujudkan perundangan harta intelek yang menepati peruntukan Perjanjian TRIPS pada akhir tahun 2001. Malaysia telah menggubal undang-undang baharu seperti Akta Reka bentuk Susun Atur Litar Bersepadu 2000 dan meminda beberapa undang-undang yang sedia ada seperti Akta Hak Cipta 1987, Akta Paten 1983, Akta Cap Dagangan 2019, dan Akta Perihal Dagangan 2011.

Secara ringkasnya, triti, persatuan dan perjanjian antarabangsa yang telah dibincangkan amatlah penting untuk perkembangan penguatkuasaan undang-undang di negara Malaysia dan negara yang lain. Hal ini demikian kerana konvensyen dan protokol sedia ada ialah perjanjian yang terhasil daripada persetujuan negara-negara yang setuju dengan peruntukan yang telah diutarakan. Secara tidak langsung, perjanjian antarabangsa memberikan tanggungjawab untuk negara mematuhi dan melaksanakan tanggungjawab berdasarkan triti dan perjanjian yang telah ditandatangani. Merujuk misi dan visi persatuan antarabangsa seperti WTO dan WIPO pula, mereka mempunyai peranan yang besar, iaitu mewujudkan polisi serta memastikan kerangka perundangan pada peringkat dalam negara berpandukan polisi yang ditetapkannya. Hal ini demikian supaya sistem perundangan yang menyentuh isu hak intelek dan gejala barang tiruan ini dapat diseragamkan di setiap negara supaya tidak wujud percanggahan.

\section{PENGUATKUASAAN UNDANG-UNDANG DI UNITED KINGDOM}

Hak Cap Dagangan di United Kingdom telah diberikan perlindungan selama bertahun-tahun sama ada melalui pendaftaran cap dagangan yang ditadbir oleh Akta Cap Dagangan 1994 atau berdasarkan "common law action of passing off", atau kedua-duanya sekali. Perlindungan diberikan sekiranya cap dagangan didaftarkan, dan akta pertama yang mentadbir pendaftaran tersebut ialah Akta Pendaftaran Cap Dagangan 1875, da mengikut akta tersebut, pendaftaran adalah berdasarkan kelas barangan. Seksyen 10 Akta tersebut mentafsirkan cap dagangan yang didaftarkan ialah "peranti, atau tanda, atau nama individu atau firma yang dicetak dalam beberapa cara tertentu dan tersendiri; atau tanda tangan bertulis atau salinan tandatangan bertulis seseorang individu atau firma; atau label tersendiri atau tiket”. Untuk pendaftaran dibenarkan, cap dagangan tersebut haruslah mempunyai salah satu ciri yang dinyatakan dalam Akta 
Pendaftaran Cap Dagangan 1875 tersebut, tetapi bagi cap dagangan yang telah wujud sebelum akta tersebut diwujudkan dibenarkan untuk didaftarkan meskipun tidak memenuhi ciri-ciri yang dinyatakan. Ciriciri cap dagangan tersebut berdasarkan seksyen 2, Akta Pendaftaran Cap Dagangan 1875 termasuklah penulisan, drama, nyanyian, muzik, lukisan, filem, ataupun rakaman suara.

Kemudian pada tahun 1883, Akta Paten, Reka Bentuk dan Cap Dagangan telah menggantikan Akta Pendaftaran Cap Dagangan 1875 di United Kingdom. Akta pada tahun 1883 ini berjaya mengurangkan kos untuk pendaftaran serta menambah kelayakan untuk mendaftar cap dagangan yang bersifat "kata-kata unik yang tidak digunakan secara umum" dan "jenama". Kemudian, perundangan dan pindaan berkenaan cap dagangan telah diluluskan pada tahun 1888, 1905, 1919, 1938 sehingga yang terkini ialah akta pada tahun 1994. Akta pada tahun 1888 dan 1905 memperincikan lagi definisi cap dagangan, akta pada tahun 1919 pula membahagikan pendaftaran cap dagangan kepada bahagian A dan bahagian B di mana sistem ini kemudiannya telah dihapuskan dalam akta yang digubal semula pada tahun 1994. Akta terkini, Akta Cap Dagangan 1994, berjaya menubuhkan rejim baharu untuk pendaftaran cap dagangan, membuat peruntukan untuk cap dagangan komuniti (Community Trademark) dan memperuntukkan pendaftaran antarabangsa, iaitu Protokol Madrid.

Pentadbiran bagi urusan harta intelek di United Kingdom adalah di bawah tanggungjawab Pejabat Harta Intelek - Intellectual Property Office (IPO). Pejabat tersebut merupakan agen eksekutif di bawah Department of Trade and Industry (DTI) oleh Jabatan Sains dan Inovasi United Kingdom. Pejabat ini bertanggungjawab untuk merangka perundangan tentang hak harta intelek, paten, reka bentuk, cap dagangan dan hak cipta. Pejabat ini ditubuhkan pada tahun 1852 dan pada ketika itu dikenali sebagai Pejabat Paten (Patent Office), yang merupakan satu-satunya pejabat di United Kingdom yang membuat pendaftaran hak paten. Kemudian pada tahun 1875-1876, pejabat ini bertanggungjawab untuk menguruskan pendaftaran reka bentuk industri dan cap dagangan. Pada tahun 2006, ekoran cadangan yang diutarakan dalam Gowers Review, pejabat ini dinamakan semula sebagai United Kingdom Intellectual Property Office (UKIPO) kerana skop tanggungjawabnya yang semakin luas, tidak sekadar hal-hal berkenaan paten sahaja. 
Jadual 2 Penguatkuasaan undang-undang di United Kingdom.

\begin{tabular}{|l|l|}
\hline Tahun & Penguatkuasaan undang-undang di United Kingdom \\
\hline 1852 & Pejabat Harta Intelek - Intellectual Property Office (IPO) \\
\hline 1875 & Akta Pendaftaran Cap Dagangan \\
\hline 1881 & Chartered Trading Standards Institute (CTSI) \\
\hline 1994 & Akta Cap Dagangan \\
\hline 2006 & 'United Kingdom Intellectual Property Office' (UKIPO) \\
\hline 2015 & Akta Hak Pengguna \\
\hline
\end{tabular}

Selain mentadbir urusan pendaftaran paten, cap dagangan dan reka bentuk untuk memastikan sistem berkenaan harta intelek di United Kingdom berjalan dengan lancar, hal-hal berkenaan penguatkuasaan juga merupakan salah satu peranan utama UKIPO. Oleh itu, National IP Crime Strategy telah dilaksanakan untuk merangka polisi dan penguatkuasaan hak intelek yang bersesuaian bagi negara tersebut. UKIPO telah bekerjasama dengan organisasi yang lain seperti polis, pihak kastam United Kingdom, dan termasuk pihak daripada pengawalan sempadan untuk melaksanakan penguatkuasaan yang sistematik bagi membanteras mana-mana kegiatan yang menceroboh hak harta intelek.

Akta Hak Pengguna 2015 yang berjaya dipinda oleh United Kingdom juga telah memberikan pengguna hak-hak yang lebih menyeluruh serta menguatkan peranannya yang penting dalam isu pembanterasan penjualan barang tiruan. Menurut seksyen 63 Jadual 2 akta tersebut, pengguna ataupun pembeli mempunyai hak dari segi undang-undang untuk memohon bagi mendapatkan pengembalian wang (refund) jika barang yang dibeli oleh mereka ialah barang tiruan. Selain itu, mereka boleh melaporkan pesalah ke Chartered Trading Standards Institute (CTSI) supaya tindakan undangundang dapat dikenakan terhadapnya. Namun begitu, jika pengguna hanya mengambil tindakan untuk melaporkan sahaja, pihak CTSI tidak dapat membantu pembeli untuk mendapatkan wang pembeli kembali.

Perbezaan peranan antara UKIPO dan MyIPO Malaysia ialah MyIPO tidak bertanggungjawab untuk penguatkuasaan polisi berkenaan harta intelek di Malaysia. Tetapi persamaan antara kedua-dua pentadbiran ini ialah tanggungjawab tidak diletakkan atas satu pentadbiran ini sahaja. Hal ini demikian kerana tugas penguatkuasaan ini memerlukan kerjasama daripada semua pihak yang berkaitan untuk membanteras kegiatan penjualan barang tiruan ini. Untuk melaksanakan tindakan serbuan atau 
Jadual 3 Ringkasan penguatkuasaan undang-undang berkaitan penjualan barang tiruan di Malaysia dan United Kingdom.

\begin{tabular}{|c|c|c|}
\hline & Malaysia & United Kingdom \\
\hline $\begin{array}{l}\text { Akta serta prinsip } \\
\text { perundangan: }\end{array}$ & $\begin{array}{l}\text { Akta Hak Cipta 1987, } \\
\text { Akta Paten 1983, Akta } \\
\text { Reka bentuk Susun Atur } \\
\text { Litar Bersepadu 2000, } \\
\text { Akta Perihal Dagangan } \\
\text { 2011, Akta Cap Dagangan } \\
2019\end{array}$ & $\begin{array}{l}\text { 'common law action of } \\
\text { passing off', Akta Cap } \\
\text { Dagangan 1994, Akta } \\
\text { Hak Pengguna } 2015\end{array}$ \\
\hline Pembahagian kuasa: & $\begin{array}{l}\text { MyIPO, KPDNHEP, pihak } \\
\text { kastam, polis, mahkamah }\end{array}$ & $\begin{array}{l}\text { 'United Kingdom } \\
\text { Intellectual Property } \\
\text { Office' (UKIPO), } \\
\text { Chartered Trading } \\
\text { Standards Institute } \\
\text { (CTSI), pihak kastam, } \\
\text { polis, mahkamah }\end{array}$ \\
\hline $\begin{array}{l}\text { Syarat-syarat untuk } \\
\text { membuat aduan: }\end{array}$ & $\begin{array}{l}\text { - Surat aduan } \\
\text { - Laporan terperinci untuk } \\
\text { menyokong surat aduan } \\
\text { - Salinan sijil pendaftaran } \\
\text { sebagai pemilik hak cap } \\
\text { dagangan yang sah } \\
\text { - Surat kuasa } \\
\text { - Pengguna boleh } \\
\text { membuat tuntutan di } \\
\text { Tribunal Tuntutan } \\
\text { Pengguna }\end{array}$ & $\begin{array}{l}\text { - Surat aduan } \\
\text { - Laporan terperinci } \\
\text { untuk menyokong surat } \\
\text { aduan } \\
\text { - Salinan sijil } \\
\text { pendaftaran sebagai } \\
\text { pemilik hak cap } \\
\text { dagangan yang sah } \\
\text { - Surat kuasa } \\
\text { - Pengguna boleh } \\
\text { memohon untuk } \\
\text { membuat pengembalian } \\
\text { wang (refund) }\end{array}$ \\
\hline $\begin{array}{l}\text { Tindakan yang akan } \\
\text { diambil oleh pihak } \\
\text { berkuasa: }\end{array}$ & \multicolumn{2}{|c|}{ Penyitaan barang, pesalah akan ditangkap } \\
\hline $\begin{array}{l}\text { Hukuman yang akan } \\
\text { dikenakan: }\end{array}$ & \multicolumn{2}{|c|}{ Denda, dipenjarakan, atau kedua-duanya sekali } \\
\hline
\end{tabular}


penyitaan, operasi ini memerlukan kerjasama pihak polis untuk memasuki premis dan melaksanakan operasi tersebut. Akta Cap Dagangan 1994 ini memberikan kuasa kepada pihak polis untuk memasuki premis dan menggeledah premis yang melakukan atau disyaki melakukan aktiviti yang melanggar hak cipta.

Walau bagaimanapun, peranan terbesar dalam penyiasatan kegiatan penjualan barang tiruan ini jatuh pada Trading Standards Department United Kingdom. Mereka mempunyai kuasa undang-undang untuk menguatkuasakan peruntukan dalam Akta Cap Dagangan 1994 dan Akta Perihal Dagangan 1968. Pegawai Trading Standards Department di CTSI memainkan peranan seperti KPDNHEP di Malaysia, iaitu mereka akan melakukan operasi pemantauan di premis-premis tertentu sekiranya mereka menerima aduan daripada pihak luar. Mereka juga mempunyai kuasa untuk membuat pemeriksaan dan melakukan penyitaan sekiranya barangan yang dijual mencurigakan, tetapi mereka tidak mempunyai kuasa untuk menangkap suspek atau penjenayah. Oleh itu, dalam keadaan yang tertentu, mereka perlu melaksanakan operasi bersama-sama dengan pihak polis. Pihak kastam dan pengawalan di sempadan juga turut memainkan peranan yang penting untuk membanteras kegiatan penjualan barang tiruan ini kerana mereka bertanggungjawab untuk menyekat kemasukan barang tiruan ini sebelum barangan tersebut memasuki setiap sempadan United Kingdom.

Tidak dinafikan bahawa penguatkuasaan ini perlu dilakukan secara peringkat demi peringkat supaya dapat menyeragamkan kuasa dan peranan bagi setiap pihak yang berkaitan dan dapat mengelakkan masalah pertindihan kuasa.

\section{Cabaran yang Dihadapi antara Kedua-dua Negara untuk Membanteras Kegiatan Penjualan Barang Tiruan}

Subtopik ini telah mengenal pasti peruntukan undang-undang yang melindungi hak harta intelek di United Kingdom yang didapati mencukupi unuk membanteras kegiatan penjualan barang tiruan ini sama ada pada peringkat luar negara atau dalam negara. Namun demikian, keupayaan pihak berkuasa melaksanakan penguatkuasaan tersebut merupakan satu cabaran yang harus dihadapi seperti yang dihadapi oleh Malaysia. Undangundang dan peruntukan hanya wujud sebagai suatu rangka sistem sahaja, manakala penguatkuasaan ialah tindakan dan komponen yang paling utama untuk memastikan rangka sistem tersebut dapat dilaksanakan. 
Walaupun undang-undang berkenaan harta intelek di Malaysia dan United Kingdom telah ditetapkan bersesuaian dengan piawaian antarabangsa, usaha berterusan dan inisiatif tertentu oleh pihak berkuasa masih diperlukan untuk melindungi kepentingan pemain pasaran asing dan pemain pasaran tempatan. Sebagai contoh, pembahagian kuasa yang berkaitan dalam usaha menangani kegiatan penjualan barang tiruan di kedua-dua negara ini dibahagikan kepada beberapa bahagian, iaitu kuasa, pihak kastam, badan pentadbiran, polis, pihak pendakwa dan mahkamah. Walaupun pembahagian kuasa ini adalah baik kerana mewujudkan kerjasama sesama agensi, namun cara ini menghalang tindakan segera diambil apabila diperlukan. Sebagai contoh, dalam situasi apabila pegawai penguat kuasa KPDNHEP atau Pegawai Trading Standards Department terpaksa mendapatkan bantuan polis untuk melakukan serbuan, penangguhan untuk memohon kerjasama tersebut mungkin akan memberikan masa yang mencukupi untuk suspek menyembunyikan atau melupuskan bukti yang relevan.

\section{KESIMPULAN}

Penguatkuasaan undang-undang dari pelbagai peringkat iaitu peringkat dalam negara dan secara antarabangsa amatlah penting, setiap peringkat memainkan peranannya masing-masing. Selain itu, kewujudan triti dan perjanjian antarabangsa adalah untuk memastikan keseragaman undangundang di dalam negara serta dapat memastikan pemakaiannya adalah secara menyeluruh. Penguatkuasaan undang-undang antara Malaysia dan United Kingdom ini adalah serupa, namun negara United Kingdom menyediakan peruntukan yang lebih efektif kepada masyarakat mereka dengan wujudnya Akta Pengguna 2015 yang memberikan pengguna untuk menuntut haknya selain daripada menumpukan peruntukan perundangan mereka kepada pihak penjual yang teraniaya sahaja.

\section{RUJUKAN}

Akta Cap Dagangan 2019.

Akta Hak Cipta 1987.

Akta Jualan Barangan 1957.

Akta Perihal Dagangan 2011.

Akta Perlindungan Pengguna 1999. 
Agarwal, S. P., S. (2016). Consumer Orientation Towards Counterfeit Fashion Products: A Qualitative Analysis. The IUP Journal of Brand Management XIII (56).

Chaudhry, P. E., \& Cesareo, L. (2017). Fake and pirated: Do consumers care? Journal of Business Strategy. Journal of Business Strategy, 38(6), 11-19.

Clunas, Craig. (1991). Superfluous things: Material culture and social status in early modern China. University of Illinois Press.

Gentry, J. W., Putrevu, S., \& Shultz, C. J. (2006). The effects of counterfeiting on consumer search. Journal of Consumer Behaviour: An International Research Review, 5(3), 245-256.

George W. Abbott, L. S. S. (1999). Trademark counterfeiting. Aspen Law \& Business.

Hew Chai Seng (t/a Pertiland Trading Co) v Metronic Integrated System Sdn Bhd \& Anor [2017] 7 MLJ 1

Jasmine Food Corporation Sdn Bhd v Leong Wai Choon \& Anor [2016] 5 CLJ 953 Johnson v Johnson, Re [1997] MLJU 328

Louis Vuitton Malletier v Megastar Shipping Pte Ltd [2017] SGHC 305

Konvensyen Berne 1986

Konvensyen Paris dan Perlindungan Hak Perindustrian 1983.

Mackey, T. K., \& Liang, B. A. (2011). The global counterfeit drug trade: Patient safety and public health risks. Journal of Pharmaceutical Sciences, 100(11), 4571-4579.

Montres Rolex S.A. v Ricardo de AG (2005) 37 IIC 573

Nurazreen, M. A. (2011). Cabaran dan kaedah dalam meningkatkan prestasi kerja pegawai penguatkuasa KPDNKK masa kini (Disertasi Doktor Falsafah tidak diterbitkan). Universiti Utara Malaysia.

Perjanjian Vienna (Vienna Agreement Establishing an International Classification of the Figurative Elements of Marks) 1973.

Protokol Madrid 1892

Sonmez, M., Yang, D., \& Fryxell, G. (2013). Interactive role of consumer discrimination and branding against counterfeiting: A study of multinational managers' perception of global brands in China. Journal of Business Ethics, 115(1), 195-211.

Tan Kim Hock Product Centre Sdn Bhd \& Anor V Tan Kim Hock Tong Seng Food Industry Sdn Bhd [2018] 2 MLJ 1

TRIPS (Agreement on Trade-Related Aspects of Intellectual Property Rights) 1994.

World Intellectual Property Organization (WIPO) 1974.

World Trade Organization (WTO) 1994. 